\title{
Sukuk Bond In Pakistan: An Analysis Of Islamic Mode Of Financing For Investors
}

\author{
Sakheela Raees \\ Lecturer Management Sciences \\ University of Management \& Technology \\ Zakir Raheem \\ Lecturer Management Sciences \\ Riphah International University Lahore \\ Anam Zakir \\ Instructor Department of Statistics \\ Virtual University Lahore
}

\begin{abstract}
Banking and financial system in an economy acts as blood circulation in body. Just as effective and efficient blood circulation ensures healthy and sound body similarly strong banking and financial system ensures economic efficiency and development. The basic objective of financial system is to find comprehensive solutions to existing practical problems. Islamic banking and financial industry is rapidly growing all over the world predominantly in Islamic countries. Islamic finance industry has arisen as best alternative to conventional financial system by providing better products and effective means of financing. The products introduced by Islamic finance industry are recognized all around the globe. Islamic banking and finance industry is making positive contribution to all segments of society like trade and industry. Islamic finance industry offer different products to investors for financing purposes. The study relates to Islamic Banking specifically focusing on Islamic bonds. Islamic bonds have been developed as capital market instrument in past few decades. The purpose of this study is to identify those factors that can increase the investment in sukuk. Present study is quantitative research in which mix method design is adopted to conduct the analysis. This study contains three questions. First question identifies the difference between conventional bonds and sukuk. Second question describes the structure of the sukuk. These questions were answered from the literature available on this field. Third question identifies those factors which enhance the investment in sukuk in Pakistan. To investigate this, a structured and self-administered questionnaire was constructed to collect the response of current and potential investors. The respondents were teachers who are teaching in University of the Punjab. The data was collected by distributing 285 questionnaires among respondents. The questionnaire consisted of two sections based on five point likert scale. The questionnaire was examined for validity and reliability. To check and determine the predictive relationship among dependent variable and independent variables linear regression model is used in this study. The questionnaire contains five independent variables; Knowledge about the Sukuk, Islamic spirit, and Return on investment, Mechanism, and Trust on issuing authority and one dependent variable, as investment in Sukuk. The empirical results of study indicates that Knowledge about the Sukuk has positive, significant and the strongest relationship with investment in Sukuk, and Islamic spirit has positive, significant and stronger relationship with investment in Sukuk. Return on investment has positive, significant and strong relationship with investment in Sukuk whereas the relationship with Mechanism and investment is positive and significant but is weaker as compared to these three variables. Moreover relationship of Trust on issuing authority is although positive but insignificant and has the weakest relationship.
\end{abstract}




\section{INTRODUCTION}

Islamic banking and finance is augmenting significant market in global finance industry. Contemporary Islamic finance in now enjoying its fourth decade and during that period Islamic finance has shown remarkable growth. In last few years, overall market growth rate is estimated to be 15 to 20 percent per annum, and on the other hand individual Islamic financial institutions have reported event faster growth. Market dynamics have been found in Islamic financial centers and different other markets (Mansoor \& Ishaq, 2008). Presently more than 300 Islamic banks and financial institutions are profitably operating their business operations from London, Los Angeles, Dubai, Karachi, Riyadh, Jakarta, Cairo and many other parts of the world. Islamic finance is rapidly growing segment of the world. It has captured the new markets such as Pakistan, China, England, America, Turkey, Syria, Lebanon and Canada, and it is difficult to predict that this development is going to slow down in future, so it has proved to be one of the best growing sectors in global financial markets (Afshar, 2013). Since there is potential growth in Islamic finance industry, Conventional banks are considering to shift their system from Conventional banking system to Islamic banking system. Couple of years ago, Kuwait Real Estate Bank has announced its conversion to entire Islamic banking system and Central Bank of Kuwait has approved it to Kuwait International Bank. Perceptions of Islamic banking have considerably developed. Islamic banking and finance has captured significant share in financial world. In Muslims countries, particularly in the west, different institutional, sectional and retail markets are selecting Islamic financial products for their investment and other financial purposes. In the presence of financial and investment opportunities, today more than seven hundred Islamic financial institutions are functioning around the world with \$ 1.2 trillion assets under more than 85 countries. Moreover USA, Europe, Africa, Central Asia and South Asians countries are offering Islamic financial services. Standard and Poor's have forecasted \$ 4 trillion market growth of Islamic finance industry (Iqbal \& Molyneux, 2005). All the practices, procedures and objectives are common to any banking and financial system whether it is conventional system or Islamic system. The main difference in these two systems consists in the methodology acquired to achieve the objectives. Conventional banking systems try to attain these objectives by using the interest based agreements while Islamic banking aims to achieve these objectives through interest free agreements. All the agreements and practices adopted in Islamic banking are permissible in Islam and all the agreements and practices adopted in Conventional banking system are not allowed in Islam (Othman \& Owen, 2001).

This resemblance of objectives and differences in the methodology of Islamic and Conventional system explains the regulatory framework which is required for Islamic financial system. Regulatory framework used in both conventional and Islamic banking system is almost same; however because of methodological difference to accomplish these objectives made it compulsory to make changes in regulatory frame work in accordance with Shariah.

This is a pragmatic way that helps circumvent the tendency of unnecessarily reinventing the wheel. It gives Islamic banking a greater opportunity to attain maximum to leverage from existing and well defined regulatory framework of the Conventional banking system. In Pakistan, Islamic banking and financial system provide response to both economic and financial needs. Efforts were started to eradicate Riba from economical system during 1970s and in order to make these efforts more important and practical significant step were exercised in 1980s. In the mid of eighties the revolution of Islamic banking spread across the country. Advance practices and model were introduced in Islamic banking system which were more efficient and effective models being implemented anywhere in the Islamic financial system across the globe (Moore, 1997). Though these arrangements could not fulfill the entire 
requirement needed in implementing full practices of Islamic banking regulations but these arrangements provided the foundation to State Bank of Pakistan to formulate current and potential strategies to launch Islamic banking in Pakistan. The step to re-launch Islamic financial system in the country was introduced in early 2001 when the Government of Pakistan made the decision to advance and promote Islamic banking system gradually which is equitable and compatible with internationally practiced Islamic banking operations. Government of Pakistan made sure that no hurdles were created in the economy while shifting the Conventional banking to Islamic banking. In this context it was decided to build and introduce a strong Islamic financial system in the country which is accessible to each individuals who wants financial services. Furthermore, State Bank of Pakistan made policies to enhance and expand the Islamic banking in all areas of the country by granting full permission to private investors to open full-fledged Islamic banks in the country and made it obligatory to already existing Conventional banks to open Islamic banking branches (Ahmad \& Safwan, 2010).

These steps boosted Islamic banking system of the country although there were regulatory and legal issues in the way to introducing new banking practices but commitment on the part of State Bank removed these obstacles. New approaches of Islamic banking provided more convenience and ease to implement Shariah compliant agreements. It gave more elasticity to Islamic financial institution in respect of Islamic financial products, instruments and Shariah compliant methodologies. These new steps proved very effective and successful. In early 2003, there was only one full-fledged Islamic bank and three Conventional banks were operating their Islamic banking branches, and now in 2015 there are six Islamic banks who are completely Islamic and twelve other Conventional banks have got the license to operate Islamic banking branches and deliver Islamic financial products (Ataullah, 2004). All major five banks of Pakistan are providing Islamic financial services while opening their separate Islamic branches or providing separate departments of Islamic banking within their Conventional branches. In recent years Islamic finance industry has offered wide range of Islamic financial products which are required by the major segment of the economy. It has also been noticed that financial industry performed well as compared to other industries in the economy. These developments not only support the financial system of the country but also provide the means of development and growth to other industries. This positive trend not only improves the overall economy of the country but also provide instruments to attract foreign direct investment in Pakistan (Akhtar \& Sadaqat, 2011).

The definition Islamic finance provides fundamental difference between Islamic finance industry and Conventional finance industry. Although it is theoretically appeared that Islamic finance industry uses same method of financing as used by the Conventional finance industry but the difference lies in the structure and application of these two industries. Islamic finance industry products have been derived over time from Murahaba which is referred as cost plus financing to Sukuk which are referred to as Islamic bonds. Islamic laws prohibits giving and taking of interest in financial contracts and as result of that countries with majority of Muslims; conventional debts market are considered in contrast of Islamic laws/Shariah (Hassan, 2012) . Islamic finance is the key feature that differentiates the Islamic economy from Conventional economy. The definition of Islamic economy has been defined by different researchers, scholars and economists. Mohsen .S. Khan who is working as senior economists in International Monetary Fund (IMF) has defined the Islamic economy as a complete system that describes a specific pattern of individuals and ways to deal with large number of business matters such as incentive system, allocation of resources, property rights, the types of economic freedom, proper role of state provides income and wealth distribution, ensuring social justice and complete system of economic decision making (Khan \& Mirakhor, 1994). 
Another definition of Islamic economy defined by Hasanuz Zaman who is Islamic economic expert in International Development Bank (IDB) as a complete knowledge and understanding of the application of injunctions, rules and regulations that give satisfaction to individuals and enable them to perform their duties to their God and to the society by avoiding inequality and injustice in the acquisition of funds and resources (Zaman, 1994). The fundamental principles, objectives, practices and procedures are same in Conventional and Islamic banking system. However methodology adopted to achieve defined objectives and goals are different in Islamic and Conventional banking system. Conventional banking industry aims to achieve these objectives using interest based contracts while Islamic banking industry seeks to achieve these objectives using interest free contracts (Zaher \& Hassan, 2001). Islamic teachings has clearly prohibited the use of interest based contracts but has allowed the trade in the following verses of Quran."Those who consume interest cannot stand (on the day of Judgment) except as one stands, who is being beaten by satan into insanity. That is they say (trade is just like interest), but Allah has prohibited interest, so whoever has received admonition from his Lord and desists may have what is just, and his affairs rests with Allah. But whoever returns (to dealing in interest), those are champions of fire, they will be abide eventually therein" (Al-Quran 2275) "Allah destroys interest and gives increase for charity. And Allah does not like every sinning disbeliever" (Al-Quran 2-276) "O you believe, fear Allah and give up what remains (due to you) of interest if you should be believe" (Al-Quran 2-278) "And if you do not, then be informed of War (against you) from Allah and His Prophet (P.B.U.H.) but if you repent you may have your principles _ Thus to no wrong nor are you wronged" (Al-Quran 2-279) Islamic teachings regarding the usury are described in the Holy Quran: "O you, who are believed, do not consume usury, doubled and multiplied, but fear Allah that you may be successful" (AlQuran 3-130) "And (for) their taking of Usury while forbidden from it and their consuming of the peoples wealth unjustly and we have prepared for the disbelievers among them a painful punishment" (Al- Quran 4-161) "And whatever you give for interest to increase within the wealth of people will not increase with Allah. But what you give in Zakat, desiring the countenance of Allah-those are multiplier" (Al-Quran 30-39) the regulatory framework used in both conventional and Islamic banking also differentiates both of them. The regulatory framework adopted in Islamic banking is purely based on Islamic Shariah practices.

Islamic banking in Pakistan is engrossed as a reaction to religious and economic needs. In order to eliminate Riba different attempts were made in 1970. However, substantial steps were taken in 1980's. In the early eighties, significant steps particularly contributed in development of Islamic banking and industry in Pakistan (Yahya et al., 2012). With the passage of time that system came apart because each was failed to resolve the issues. Nevertheless, this development provided basics to the State Bank of Pakistan in the formation of new Islamic banking strategies in Pakistan. In 2001, Government of Pakistan determined to develop new approaches and promoted existing strategies which were equitable and compatible in accordance with the International practices (Khattak, 2010).

Entrepreneurship is the basis of western capitalistic system. The new business creation and developing new ideas have certainly provided benefits to the society, but without investing in opportunities; continuous development, innovation and commercial growth would have been procrastinated. Presently Islamic finance has the potential opportunities to encourage entrepreneurship in Muslims societies (Kuran, 2008). Muslims have substantial financial resources in hand have always faced the question about how to safeguard their financial resources while remaining faithful to the laws of Islamic finance. Islam forbids the hoarding of money because when the money is hoarded, it prevents from attaining its desired objectives (Kayed \& Hassan,2011). Islam has clearly defined principles about the hoarding of money in 
Holy Quran as" Those who hoard up gold and silver and do not spend in the way of ALLAH, give them the tidings of painful punishment". The legitimate substitute of hoarding is to invest it by having a large range of new opportunities.

Financial resources can be deposited in different bank accounts to earn fixed rate of interest on them. These earning are in shape of fixed interest that is considered unlawful, thus forbidden and condemned in Islam. There are many other alternatives available where investment could be made in form of import/export, stock market and real estate and many other alternatives. This type of investment consists of productive, unproductive and sometimes destructive business activities. Islam only approves of those business resources in the way of ALLAH, which involves making investment in business related activities which are moral, productive and desirable by the society (Salarzehi \& Armesh, 2010). Therefore Muslims investors are encouraged to invest in productive trade activities or to start his/her own business entity or entering into partnership agreement. It is significant to describe here that every Muslim investor with extra money to invest, has some special personality traits, qualities, skills and abilities to be an entrepreneur. Islamic financial system provides best solution to this situation by allowing an investor to have some share in business venture by partnership agreement with potential entrepreneur who has not enough money to start his own business entity. Islamic banking and finance provides entrepreneurial opportunities to investors through investing in Sukuk, Musharaka and Mudaraba agreements.

Musharaka is an Arabic word which means "partnership". Musharaka and Mudaraba are two major partnership agreements based on profit and loss sharing principles. Musharaka agreement is just like Mudaraba agreement the only difference is that in Musharaka the entrepreneur not only provides skills and abilities but also puts capital in the business venture. Musharaka provides both the entrepreneur and the financial institution chance not only to share business assets and working capital but also to participate in the management of business. Both parties have full control on the management of the business. Profit is shared according to pre-defined ratios which are based on the percentage of contribution of both parties to the business venture. Losses are also shared according to the percentage of share in the business venture (Rammal, 2004). Research has identified that Muslims in the interest free economy not only increases their own profits but also try to increase the financial positions of their partners. This is the true spirit which improves the essence of entrepreneurship. Islamic entrepreneurship provides social economic conditions to the society by promoting and emphasizing on the Zakat. Zakat is very efficient instrument to gain the ultimate objective of social justice. It is a meaningful tool which reflects in these distinctive groups of Muslims, the giver, the taker, and the needy Muslims. In comparison to non-Muslim societies where public pays heavy taxes and does not expect any reward in return just only better government service (Qasaymeh, 2011). On the other hand, Muslims give due amount of Zakat whole heartedly. They do so because they have perceived that while paying Zakat, they are contributing towards social economic justice. Moreover, Zakat provide essence of unity, respect, and equal distribution of wealth. Islam clearly motivates the Muslims towards productive business activities which help the societies in eradication of poverty and equal distribution of wealth.

\section{OBJECTIVES OF THE STUDY}

The purpose of this study is to understand and review the investment opportunities provided by Islamic finance. Islamic finance provides Islamic bonds to investors who want to make Shariah compliant investment. The purpose and objectives of the study are:

- To gauge the difference between Conventional and Islamic banking.

- To identify the major differences in Conventional and Islamic bonds

- To understand the viability and applicability of Islamic bonds 
- To identify how Islamic bonds are structured and operated

- How to make investment in Sukuk

- To increase the knowledge and understanding of Islamic bonds to both individual and corporate investors.

- What are important factors required to make investment in Islamic bonds?

- Which factors are more significant on which investment in Islamic finance depends?

\section{RESEARCH QUESTIONS}

This research aims to investigate why the Muslim investors are reluctant to invest in Islamic financial products like Sukuk and what are the basic variables that differentiate the Conventional bonds from Islamic bonds (Sukuk). This study seeks to give answers to the following specific questions:

- What are the key differences between Conventional bonds and Islamic bonds?

- What are structures of the Sukuk in Islamic finance?

- Which are the factors that encourage the investors to invest in Islamic Bonds?

\section{LITERATURE REVIEW}

Numbers of studies are available on Islamic finance and its products. Though prominent work has been done by Muslim and non-Muslim researchers but as Islamic finance is a newly developed industry so the researchers of these studies sometimes face the issue of scarcity of data. This study has three dimensions i.e Islamic finance, Entrepreneurship and Sukuk. Before moving forward, this research firstly probe what Islamic finance is? Islamic banking and finance is growing speedily in the entire world and especially in Pakistan. On the contrary, Conventional banking system is notably falling in all those countries where the system of capitalism and interest based system is prevailing from hundreds of years (Khan,2010). These countries are now manipulating the interest rates to gain the desired results but they have failed. In financial crisis large numbers of companies and financial institutions have been vanished from the financial industry. After the financial crisis, Islamic financial industry has introduced itself as a big alternative to Conventional financial system (Maurer, 2005). Islamic banking has evidenced significant development in short span of time. Islamic financial industry is not only expanding in Muslims countries but Islamic financial products are also gaining popularity in non-Muslims countries (Siddiqi, 1983). Islamic banking and financial industry has developed not merely in terms of its magnitude but also in terms number of players. It has grown to more than 50 countries around the globe such as in Pakistan, Iran, Bangladesh, Sudan, Indonesia and Malaysia Islamic banking is operating parallel to Conventional banking practices. The operations of Islamic banking and finance industry are not just limited to Islamic countries. In august 2004, Government of Britain allowed the license to Islamic bank of Britain to start its Islamic financial operation and it was the first bank in any non-Islamic country to engage in Islamic financial business (Chong \& Liu, 2009). In recent years, financial institutions have showed fast paced dynamic and competitive environment, out of these financial institutions Islamic financial institutions have gained the attention of both contemporary and Islamic economists. Islamic banks are expanding all around the world and many developed economies are starting to value the greatest demand of Islamic financial products (Yudistira, 2003). The importance of Islamic finance was described in Holy Quran fourteen hundreds years ago. The development of Islamic finance have experienced ups and downs. In its evolutionary phase it is observed in the final chapter of $20^{\text {th }}$ century that most Islamic financial institutions developed and shaped, Islamic banks were set up to operate in accordance with shariah principles for instance in 1983 there was only one bank in Malaysia which was providing Islamic financial products and services but now there are more than 30 banks which are providing Islamic financial product and services (Halim et al.,2001). Another advocates of 
Islamic finance industry describe that the development and emergence of Islamic finance industry is a phenomena which has attracted considerable interest in financial world. Islamic financial industry has given innovative solutions to global financial system and because of this reason Islamic finance is seen as fast-based banking niche. Islamic countries and particularly in the west most financial institutions are choosing Islamic finance for their financing and investment purposes (Salem, 2008).It has been evidenced that before the inception of Islamic finance industry global financial system has faced many financial crisis after each five years which caused the substantial demand of Islamic financial products and Islamic finance arose to set aside the Conventional financial system to meet demand and most of Muslims researchers started writing about Islamic finance. Since 1970 they mostly studied and wrote about the patterns and development of Islamic finance industry. These scholars not only stressed to eradicate Riba from financial system but also provided best alternatives to replace Riba from global financial system (Mirakhor \& Smolo, 2014). A rapid and significant growth in international financial system has been traced over the last fifteen years and it is due to the Islamic banking and finance industry. Now days there are more than 300 hundred Islamic financial institutions around the globe with estimated value of asset US\$200 and $\$ 300$ and this growth is increasing with the passage of time (Pollard \& Samers, 2007). Countries such as Pakistan, Bahrain, Iran and Malaysia have converted their Conventional banking system to Islamic banking system and Conventional banks in these countries are also shifting their investment towards Islamic banking system (Henry \& Wilson, 2004). Islamic finance industry is considerably growing worldwide and this continuous growth has compelled the international financial institutions, national regulatory authorities, international standard setters, policy makers and research scholars to examine different dimension of Islamic financial intermediation from their own point of view (Hawary \& Grais, 2004). Many global financial institutions have opened their cells to deal with Muslims client. International Monetary Fund (IMF), Word Band and IFC and ADBP, are now considering to formulate their policies to deal with Islamic financial industry. (Awan, 2009). Another author defined Islamic banking as financial institution that function with objectives to exercise and realize the economic and financial rules of Shariah in banking industry (Hanan, 2010) . The other dimension of this study is entrepreneurship. Entrepreneurship is an ancient concept. The concept of entrepreneurship was first introduced two hundred and fifty years ago. The practices of entrepreneurship are coming from the ages where tribes and villages trade between each other (Drucker, 2014). Research has different approaches to describe and elaborate the concept of entrepreneurship. The major research in the field of entrepreneurship has identified that the concept of entrepreneurship has three categories; management of entrepreneurship, the results of entrepreneurship and the causes of entrepreneurship. The concept of entrepreneurship is developing more deeply from last two decades because of globalization. Competitiveness has increased both at national and international levels which has acknowledged the significance of entrepreneurship in established companies to achieve competitive advantage and its sustainability. Entrepreneurship is the collection of competitive aggressiveness, risk taking, pro activeness and innovativeness (Aktan \& Bulut, 2008).

\section{Conceptual Model}

In present research, 6 variables are considered for analysis. Out of these 5 are independent variables and 1 is dependent variable. The conceptual model of these six variables is exhibited below. 


\section{Conceptual Model for Research}

Independent Variables

\section{Dependent Variable}

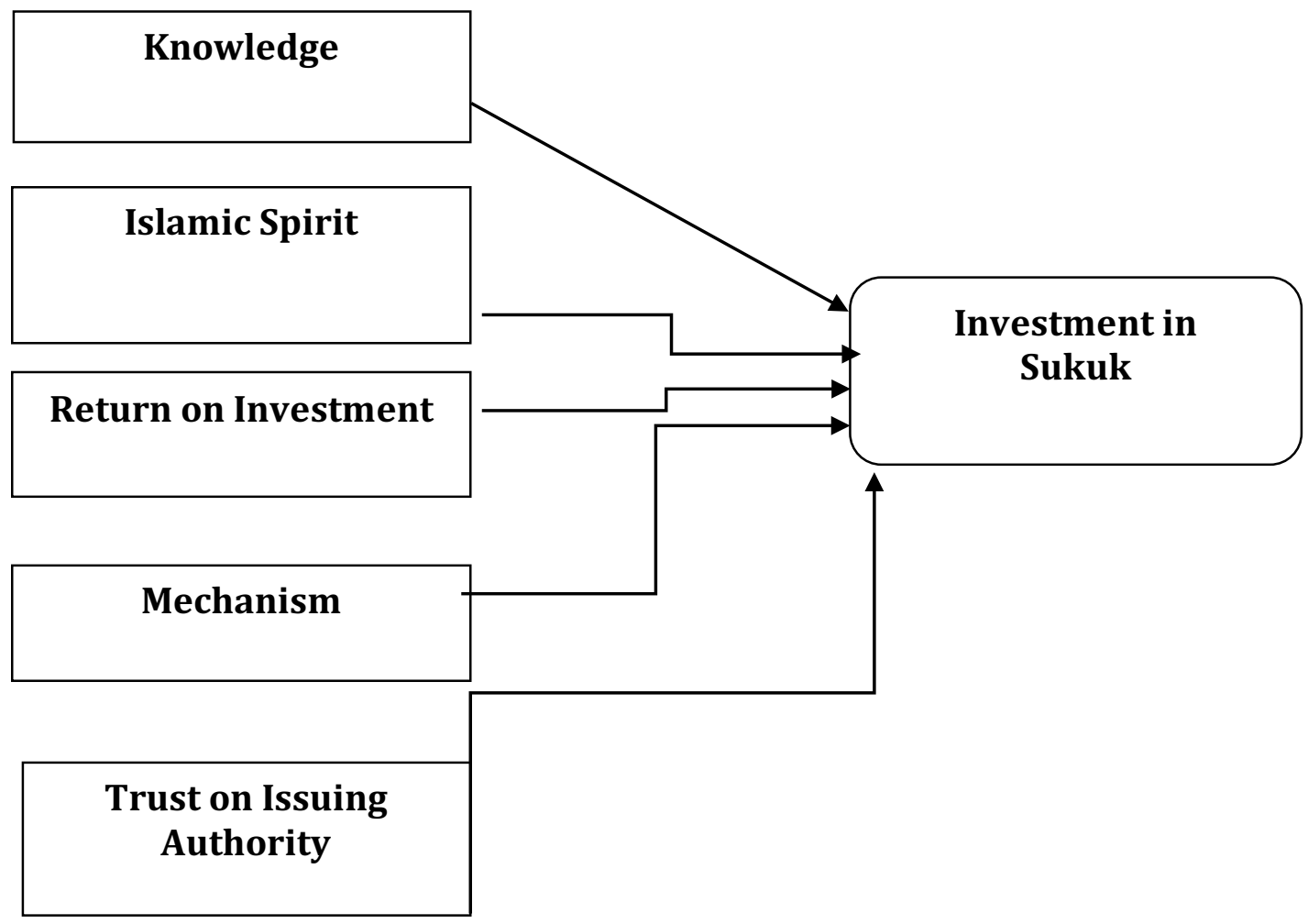

RESEARCH METHODOLOGY

This chapter comprises of research design, population and sample, sampling technique, research instrument, data collection and pilot study of the research instrument. This design of this study is cross sectional. Cross sectional design of the study is that in which data is gathered from population or sample at one point in time from different elements of the population. Cross sectional design in mostly used and appropriate in qualitative and quantitative research studies. Total Population is 1084 which include 653 male faculty members and 431 female faculty members (PU, 2012) Population of the study consists of all the teachers working in Punjab University whether they are working in business schools or social sciences departments. The total number of population mentioned above is 1084 so this study was conducted by selecting a sample size of 285 from the population (Krejcie \& Morgan, 1970). Simple random sampling technique is used for the collection of data. 15 departments were selected and the questionnaire was distributed to the available faculty members.

Structured questionnaire is used in this study. The questionnaire consists of two sections. Section A provides the demographical information about the respondents such as gender, nature of job, marital status, designation, age, qualification, experience with current organization and total job experience. Section B comprises of the questions based on independent variables such as Knowledge about the Sukuk, Islamic spirit, Return on investment, Mechanism and Trust on issuing authority and dependent variable such as Investment in Sukuk. In the establishment of questionnaire, 5 point likert scale is used to get the responses ranging from 5 strongly agree 4 agree 3 neutral 2 disagree and 1 strongly disagree (Dawes, 2008). 
It is primary but quantitative study so the structured and self-administered questionnaire was used for the collection of Data. Punjab University is the largest university of the Pakistan so it was impossible for the researcher to visit the all the departments and campuses located at different parts of the country so in this respect the researcher personally visited the departments which are directly and indirectly related to business studies located in new campus University of the Punjab. Total 300 questionnaires were distributed among 15 departments 20 questionnaires in each department. 285 questionnaires were received while 15 questionnaires were neither filled nor complete. Total 285 questionnaires were used for analysis.

\section{Correlation Analysis}

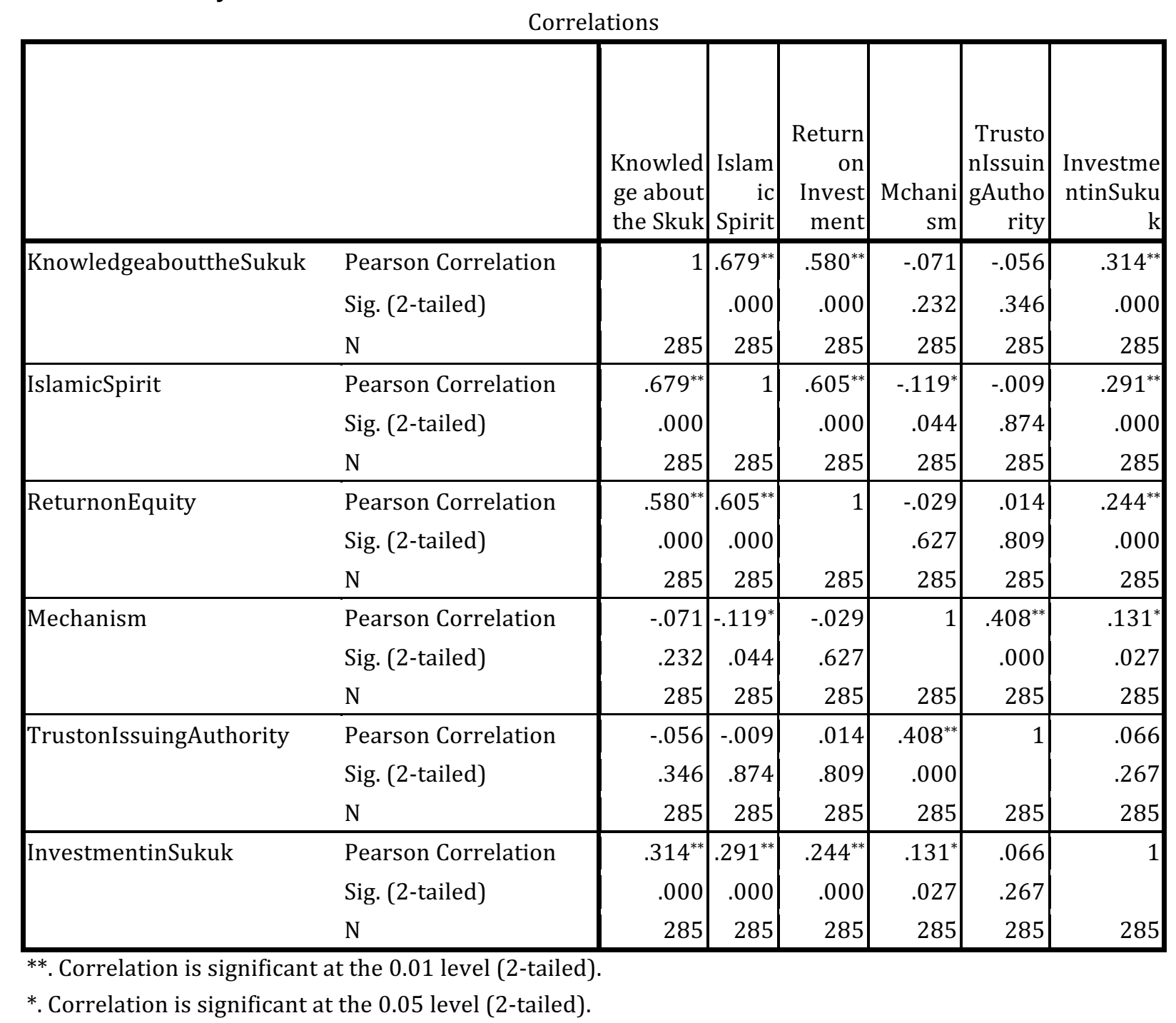

Above table provides the correlation matrix of the study whereby investment in Sukuk is considered dependent variable and Knowledge about the Sukuk, Islamic spirit, Return on investment, Mechanism, and Trust on issuing authority are independent variables. The first independent variable is knowledge about the Sukuk which has positive relationship with the dependent variable investment in Sukuk, as indicated by the correlation coefficient of 0.314.

The relationship although is weak but is significant at $1 \%$ level of significance. The second independent variable is Islamic spirit which has positive relationship with the dependent variable investment in Sukuk, as indicated by the correlation coefficient of 0.291 . The relationship although is weak but is significant at $1 \%$ level of significance. Third independent 
variable is Return on equity which has positive relationship with the dependent variable investment in Sukuk, as indicated by the correlation coefficient of 0.244 , relationship although is weak but significant at $1 \%$ level of significance. Fourth independent variable is Mechanism which has positive relationship with the dependent variable investment in Sukuk, as indicated by correlation coefficient of 0.131 , the relationship is however weak but is significant at $5 \%$ level of significance. The fifth independent variable is Trust on issuing authority has positive relationship with the dependent variable investment in Sukuk as indicated by correlation coefficient of 0.066 . The relationship is weak and is insignificant. Knowledge about the Sukuk (I.V) has relatively stronger impact on investment in Sukuk (D.V), than trust on issuing authority (I.V) is although insignificant with regards to investment in Sukuk (D.V), while variable mechanism (I.V) although is significant but had weakest relationship with investment in Sukuk (D.V) among all independent variables, stronger then that was relationship of return on equity (I.V) and after that is variable Islamic spirit (I.V).

\section{REGRESSION ANALYSIS}

Model Summary

\begin{tabular}{|c|c|c|c|c|}
\hline Model & $\mathrm{R}$ & R Square & $\begin{array}{c}\text { Adjusted R } \\
\text { Square }\end{array}$ & $\begin{array}{c}\text { Std. Error of the } \\
\text { Estimate }\end{array}$ \\
\hline 1 & $.372^{\mathrm{a}}$ & .138 & .123 & .23729 \\
\hline
\end{tabular}

a. Predictors: (Constant), Trust on Issuing Authority, Islamic Spirit, Mechanism, Return on investment, Knowledge about the Sukuk

Table shows that $\mathrm{R}^{2}$ is 0.138 indicating almost $14 \%$ variations in dependent variable investment in Sukuk is explained by independent variables included in the model Knowledge about the Sukuk, Islamic spirit, Return on investment, Mechanism and Trust on issuing authority.

\begin{tabular}{|c|c|c|c|c|c|c|}
\hline \multicolumn{7}{|c|}{$\begin{array}{c}\text { ANOVA } \\
\text { ANOVA }^{b}\end{array}$} \\
\hline & Model & Sum of Squares & $\mathrm{df}$ & Mean Square & $\mathrm{F}$ & Sig. \\
\hline 1 & Regression & 2.520 & 5 & .504 & 8.951 & $.000^{\mathrm{a}}$ \\
\hline & Residual & 15.709 & 279 & .056 & & \\
\hline & Total & 18.229 & 284 & & & \\
\hline
\end{tabular}

a. Predictors: (Constant), Trust on Issuing Authority, Islamic Spirit, Mechanism, Return on Equity, Knowledge about the Sukuk

b. Dependent Variable: Investment in Sukuk

Table shows F statistics is 8.951 which indicate that model is good fit. 
Table No 6.3 Coefficients

Coefficients ${ }^{\mathrm{a}}$

\begin{tabular}{|c|c|c|c|c|c|c|}
\hline \multirow{2}{*}{\multicolumn{2}{|c|}{ Model }} & \multicolumn{2}{|c|}{ Un standardized Coefficients } & \multirow{2}{*}{$\begin{array}{c}\begin{array}{c}\text { Standardized } \\
\text { Coefficients }\end{array} \\
\text { Beta }\end{array}$} & \multirow[b]{2}{*}{$\mathrm{T}$} & \multirow[b]{2}{*}{ Sig. } \\
\hline & & B & Std. Error & & & \\
\hline \multirow[t]{6}{*}{1} & (Constant) & 1.581 & .584 & & 2.710 & .007 \\
\hline & $\begin{array}{l}\text { Knowledge about the } \\
\text { Sukuk }\end{array}$ & .192 & .076 & .201 & 2.532 & .012 \\
\hline & Islamic Spirit & .141 & .078 & .148 & 1.812 & .071 \\
\hline & Return on Equity & .042 & .072 & .043 & .585 & .559 \\
\hline & Mechanism & .229 & .088 & .159 & 2.586 & .010 \\
\hline & Trust on Issuing Authority & .023 & .109 & .013 & .214 & .831 \\
\hline
\end{tabular}

a. Dependent Variable: Investment in Sukuk

Table no 6.3 explains first independent variable of the study is knowledge about the Sukuk which provide $\beta$ coefficient 0.192 along with $t$ statistics of 2.532 indicating that knowledge about the Sukuk has significant and positive relationship with investment in Sukuk. This leads us to accept our first hypothesis that there is knowledge about the Sukuk has significant impact on investment in Sukuk, second independent variable of the study is Islamic spirit which provides $\beta$ coefficient 0.141 along with t statistics of 1.812 indicating that Islamic spirit has significant and positive relationship with investment in Sukuk, which leads us to accept out second hypothesis which is Islamic spirit has significant impact on investment in Sukuk, third independent variable of the study is return on investment which provides $\beta$ coefficient 0.042 along with $t$ statistics of 0.585 indicating that return on investment has insignificant relationship with investment in Sukuk, which leads us to reject our third hypothesis which is return on investment has significant impact on investment in Sukuk. Fourth independent variable of the study is mechanism which provides $\beta 0.229$ along with t statistics 2.586 which indicating that mechanism has significant and positive impact on investment in Sukuk, which leads us to accept our fourth hypothesis that mechanism has significant impact on investment in Sukuk, our fifth independent variable of the study is trust on issuing authority which provides $\beta 0.023$ along with t statistics of 0.214 which indicates that trust on issuing authority has insignificant relationship with investment in Sukuk which leads us to reject our fifth hypothesis that is issuing authority has significant impact on investment in Sukuk.

\section{CONCLUSION}

Islamic financial institutions use different techniques to increase investment in Sukuk. These techniques significantly enhance the investment in Sukuk, This study is an attempt to achieve this objective about how to increase investment in Sukuk. Empirical results of this research clearly depicts that knowledge about the Sukuk has positive, significant and the strongest relationship with investment in Sukuk, Islamic spirit has positive, significant and stronger relationship with investment in Sukuk, Return on equity has positive and significant relationship with investment in Sukuk, Mechanism has positive and significant relationship with investment in Sukuk but this relationship although is weak. The relationship between trust on issuing authority and investment in Sukuk is positive but is insignificant.

This study explored the determinants of investment while making investment in Islamic financial products such as Sukuk. This research elaborates different types of Sukuk, salient features associated with these Sukuk, structures of these Sukuk, and practices and procedures of these Sukuk in Islamic finance industry. 


\section{References}

Afshar, T. A. (2013). Compare and contrast Sukuk (Islamic Bonds) with conventional bonds, are they compatible?. Journal of Global Business Management, 9(1), 44.

Ahmad, A., Saif, I., \& Safwan, N. (2010). An empirical investigation of Islamic banking in Pakistan based on perception of service quality. African journal of business management, 4(6), 1185.

Akhtar, M. F., Ali, K., \& Sadaqat, S. (2011). Liquidity risk management: a comparative study between conventional and Islamic banks of Pakistan. Interdisciplinary Journal of Research in Business, 1(1), 35-44.

Aktan, B., \& Bulut, C. (2008). Financial performance impacts of corporate entrepreneurship in emerging markets: A case of Turkey. European Journal of Economics, Finance and Administrative Sciences, 12(8), 1530-2275.

Al-Salem, F. (2008). The size and scope of the Islamic finance industry: An analysis. International Journal of Management, 25(1), 124.

Ataullah, A., Cockerill, T., \& Le, H. (2004). Financial liberalization and bank efficiency: a comparative analysis of India and Pakistan. Applied Economics, 36(17), 1915-1924.

Chong, B. S., \& Liu, M. H. (2009). Islamic banking: interest-free or interest-based?. Pacific-Basin Finance Journal, 17(1), 125-144.

Dawes, J. (2008). Do data characteristics change according to the number of scale points used. International journal of market research, 50(1), 61-77.

Drucker, P. (2014). Innovation and entrepreneurship. Routledge.

EI-Hawary, D., Grais, W., \& Igbal, Z. (2004). Regulating Islamic financial institutions. World Bank Policy Research Working Paper, 3227.

Hamid, A., \& Nordin, N. (2001). A study on Islamic banking education and strategy for the new millenniumMalaysian experience. International Journal of Islamic Financial Services, 2(4), 3-11.

Hassan, H. H. (2012). Comments on Discussion Papers and Notes submitted for the Harvard-LSE Workshop on Sukuk. Retrieved on, 12.

Hisham Yahya, M., Muhammad, J., \& Razak Abdul Hadi, A. (2012). A comparative study on the level of efficiency between Islamic and conventional banking systems in Malaysia. International Journal of Islamic and Middle Eastern Finance and Management, 5(1), 48-62.

Iqbal, M., \& Molyneux, P. (2005). Thirty Years of Islamic Banking: Theory and Practice.

Kayed, R. N., \& Hassan, M. K. (2011). The global financial crisis and Islamic finance. Thunderbird International Business Review, 53(5), 551-564.

Khan, F. (2010). How 'Islamic'is Islamic banking?. Journal of Economic Behavior \& Organization, 76(3), 805-820.

Khan, M. S., \& Mirakhor, A. (1994). Monetary management in an Islamic economy. Islamic Economics, 6(1).

Khattak, N. A. (2010). Customer satisfaction and awareness of Islamic banking system in Pakistan. African Journal of Business Management, 4(5), 662.

Krejcie, R. V., \& Morgan, D. W. (1970). Determining sample size for research activities. Educational and psychological measurement, 30(3), 607-610.

Kuran, T. (2008). The scale of entrepreneurship in Middle Eastern history: Inhibitive roles of Islamic institutions.

Mansoor Khan, M., \& Ishaq Bhatti, M. (2008). Islamic banking and finance: on its way to globalization. Managerial Finance, 34(10), 708-725.

Maurer, B. (2005). Mutual life, limited: Islamic banking, alternative currencies, lateral reason. Princeton University Press.

Moore, P. (1997). Islamic finance: A partnership for growth. London: Euromoney Publications.

Othman, A., \& Owen, L. (2001). Adopting and measuring customer service quality (SQ) in Islamic banks: a case study in Kuwait finance house. international journal of Islamic financial services, 3(1), 1-26.

Pollard, J., \& Samers, M. (2007). Islamic banking and finance: postcolonial political economy and the decentring of economic geography. Transactions of the Institute of British Geographers, 32(3), 313-330.

PU. (2012). Fact Book 2012. Lahore: Punjab University Press. 
Qasaymeh, K. (2011). Islamic banking in South Africa: between the accumulation of wealth and the promotion of social prosperity. Comparative and International Law Journal of Southern Africa, 44(2), 275-292.

Rammal, H. G. (2004). Financing through musharaka: principles and application.

Salarzehi, H., Armesh, H., \& Nikbin, D. (2010). Waqf as a social entrepreneurship model in Islam. International Journal of Business and Management, 5(7), 179.

Siddiqi, M. N. (1983). Banking without interest (Vol. 5). Leicester: Islamic Foundation.

Smolo, E., \& Mirakhor, A. (2014). Limited purpose banking (LPB) and Islamic finance: Could LPB model be applied to Islamic finance?. Humanomics, 30(2), 122-135.

Yudistira, D. (2003). Efficiency in Islamic banking: An empirical analysis of 18 banks. Islamic financial architecture, 479.

Zaher, T. S., \& Kabir Hassan, M. (2001). A comparative literature survey of Islamic finance and banking. Financial Markets, Institutions \& Instruments, 10(4), 155-199.

Zaman, S. H. (1984). Definition of Islamic economics. Journal of Research in Islamic Economics, 1(2), 49-50.

Dear Respondent (s)

\section{QUESTIONNAIRE}

We are conducting a survey to investigate why people are not investing in Islamic bonds. We shall appreciate it if you could complete the following questionnaire. Any information in connection with this study that can be identified with you will remain confidential. In any report or publication no individual will be identified and only group data will be presented. If you have any question regarding this research. Thank You!

\section{DEMOGRAPHIC INFORMATION}

The following information is required only for statistical purposes. Please do not provide any personal information that helps in identifying you.

\begin{tabular}{|c|c|c|c|c|}
\hline Gender & & & Male & Female \\
\hline Nature of Job & & Visiting & Contract & Pemanent \\
\hline Marital status & & & Single & Married \\
\hline $\begin{array}{l}\text { Designation } \\
\text { Lecturer }\end{array}$ & & $\begin{array}{l}\text { Assistant } \\
\text { Professor }\end{array}$ & $\begin{array}{l}\text { Associate } \\
\text { Professor }\end{array}$ & Professor \\
\hline Age & Less than 35 & $\begin{array}{l}35 \text {-less than } \\
40\end{array}$ & $40-45$ & Above 45 \\
\hline Qualification & & Masters & M.Phil. & Ph.D. \\
\hline $\begin{array}{l}\text { Experience with current } \\
\text { Organization }\end{array}$ & Upto2 years & Up to 5 years & Up to 10 years & $\begin{array}{l}10 \text { years or } \\
\text { more }\end{array}$ \\
\hline Total Job Experience & Upto2 years & Up to 5 years & Up to 10 years & $\begin{array}{l}10 \text { years or } \\
\text { more }\end{array}$ \\
\hline
\end{tabular}

The Response Scale is as follow

\section{SECTION B}
1. Agree
2. Strongly Agree
3. Undecided or Neutral
4. Disagree
5. Strongly disagree

For statistical purpose only. Place a tick where appropriate. 


\section{KNOWLEDGE ABOUT THE SUKUK}

The following statements are used to determine the knowledge of investors about the Islamic bonds while investing in Islamic bonds. Please choose a number from 1 to 5 to indicate your level of agreement with each statement

\begin{tabular}{|c|c|c|c|c|c|c|c|c|c|}
\hline & $\begin{array}{c}1 \\
\text { Strongly Disagree }\end{array}$ & $\begin{array}{c}2 \\
\text { Disagree }\end{array}$ & $\begin{array}{c}3 \\
\text { Neutral }\end{array}$ & $\begin{array}{c}4 \\
\text { Agree }\end{array}$ & $\begin{array}{c}5 \\
\text { Stron }\end{array}$ & sly & Igr & & \\
\hline 1 & Sukuk are Islamic bo & & & & 1 & 2 & 3 & 4 & 5 \\
\hline 2 & Sukuk provide bette & opportunit & for investr & & 1 & 2 & 3 & 4 & 5 \\
\hline 3 & Sukuk are administe & ed on best & ctices & & 1 & 2 & 3 & 4 & 5 \\
\hline 4 & Issuing authority of & kuk ensur & ll validity & issuing Sukuk & 1 & 2 & 3 & 4 & 5 \\
\hline
\end{tabular}

\section{ISLAMIC SPIRIT}

The following statements are used to measure the Islamic spirit of investors while investing in Islamic bonds. Please choose a number from 1 to 5 to indicate your level of agreement with each statement.

\begin{tabular}{|c|c|c|c|c|c|c|c|c|c|}
\hline \multicolumn{2}{|c|}{$\begin{array}{c}1 \\
\text { Strongly Disagree }\end{array}$} & $\begin{array}{c}2 \\
\text { Disagree }\end{array}$ & $\begin{array}{c}3 \\
\text { Neutral }\end{array}$ & $\begin{array}{c}4 \\
\text { Agree }\end{array}$ & \multicolumn{5}{|c|}{ Strongly Agree } \\
\hline 1 & \multicolumn{4}{|c|}{$\begin{array}{l}\text { Islamic bonds are structured and operated according to Sharia } \\
\text { principles. }\end{array}$} & 1 & 2 & 3 & 4 & 5 \\
\hline 2 & \multicolumn{4}{|c|}{$\begin{array}{l}\text { Islamic bonds are based on real economic activity not on debt } \\
\text { instrument. }\end{array}$} & 1 & 2 & 3 & 4 & 5 \\
\hline 3 & \multicolumn{4}{|c|}{ Islamic bonds are approved to be Halal by Sharia scholars. } & 1 & 2 & 3 & 4 & $J$ \\
\hline 4 & \multicolumn{4}{|c|}{$\begin{array}{l}\text { The assets on which Islamic bonds are based are Sharia compliant } \\
\text { assets. }\end{array}$} & 1 & 2 & 3 & 4 & 5 \\
\hline
\end{tabular}

\section{RETURN ON INVESTMENT}

The following statements are used to ascertain the return on investment in Islamic bonds. Please choose a number from 1 to 5 to indicate your level of agreement with each statement.

\begin{tabular}{|c|c|c|c|c|c|c|c|c|}
\hline & $\begin{array}{c}1 \\
\text { Strongly Disagree }\end{array}$ & $\begin{array}{c}2 \\
\text { Disagree }\end{array}$ & $\begin{array}{c}3 \\
\text { Neutral }\end{array}$ & $\begin{array}{c}5 \\
\text { Stron }\end{array}$ & gly & gr & & \\
\hline 1 & Return on investmen & is not fixec & Islamic bonds & 1 & 2 & 3 & 4 & 5 \\
\hline 2 & $\begin{array}{l}\text { In Islamic bonds bot } \\
\text { defined ratio betwee }\end{array}$ & $\begin{array}{l}\text { profit and } \\
\text { issuer and }\end{array}$ & $\begin{array}{l}\text { is shared according to pre- } \\
\text { holder. }\end{array}$ & 1 & 2 & 3 & 4 & 5 \\
\hline 3 & $\begin{array}{l}\text { Islamic bonds holder } \\
\text { bonds holder. }\end{array}$ & ace least & compare to conventional & 1 & 2 & 3 & 4 & 5 \\
\hline 4 & $\begin{array}{l}\text { Islamic bonds give } \mathrm{p} \\
\text { bonds are based. }\end{array}$ & ial owner & $\mathrm{n}$ the asset on which Islamic & 1 & 2 & 3 & 4 & 5 \\
\hline
\end{tabular}




\section{MECHANISM}

The following statements are used to know the mechanism of Islamic Bonds. Please choose a number from 1 to 5 to indicate your level of agreement with each statement.

\begin{tabular}{|c|c|c|c|c|c|c|c|c|c|}
\hline \multicolumn{2}{|r|}{$\begin{array}{c}1 \\
\text { Strongly Disagree }\end{array}$} & $\begin{array}{c}2 \\
\text { Disagree }\end{array}$ & $\begin{array}{c}3 \\
\text { Neutral }\end{array}$ & $\begin{array}{c}4 \\
\text { Agree }\end{array}$ & \multicolumn{4}{|c|}{ Strongly Agree } & \\
\hline 1 & $\begin{array}{l}\text { Management and op } \\
\text { understand for curre }\end{array}$ & $\begin{array}{l}\text { rations of Is } \\
\text { t and potel }\end{array}$ & $\begin{array}{l}\text { ic bonds } \\
\text { l investor: }\end{array}$ & simple to & 1 & 2 & 3 & 4 & 5 \\
\hline 2 & $\begin{array}{l}\text { Islamic bonds are no } \\
\text { business or project. }\end{array}$ & lebt but jo & wnership & he asset, & 1 & 2 & 3 & 4 & 5 \\
\hline 3 & Islamic bonds are iss & ed by statu & of IPO (In & Public Offering) & 1 & 2 & 3 & 4 & J \\
\hline 4 & $\begin{array}{l}\text { Islamic bonds can be } \\
\text { Market). }\end{array}$ & aded intc & ndary $\mathrm{m}$ & (Money & 1 & 2 & 3 & 4 & 5 \\
\hline
\end{tabular}

\section{TRUST ON ISSUING AUTHORITY}

The following statements are used to ascertain the trust of investor in issuing authority of Islamic Bonds. Please choose a number from 1 to 5 to indicate your level of agreement with each statement.

\begin{tabular}{|l|l|l|l|l|l|l|}
\hline \multicolumn{1}{|c}{\begin{tabular}{l}
1 \\
\multicolumn{1}{|c|}{$\begin{array}{l}\text { Strongly Disagree } \\
\text { Disagree }\end{array}$}
\end{tabular} Neutral 4 Agree } & \multicolumn{4}{c|}{5} \\
\hline 1 & Islamic bonds are issued under Sharia board of issuing authority & 1 & 2 & 3 & 4 & 5 \\
\hline 2 & $\begin{array}{l}\text { Islamic bonds issuer provides inherent right to the investors about } \\
\text { the use of investment, nature of underlying asset and other } \\
\text { particulars. }\end{array}$ & 1 & 2 & 3 & 4 & 5 \\
\hline 3 & Issuer of Sukuk manages the funds with honest intent. & 1 & 2 & 3 & 4 & 5 \\
\hline 4 & $\begin{array}{l}\text { Sukuk issuer invests the investor's fund into legal business } \\
\text { activities. }\end{array}$ & 1 & 2 & 3 & 4 & 5 \\
\hline
\end{tabular}

\section{INVESTMENT IN SUKUK}

The following statements are used to ascertain the desire of investors for investing in Sukuk. Please choose a number from 1 to 5 to indicate your level of agreement with each statement.

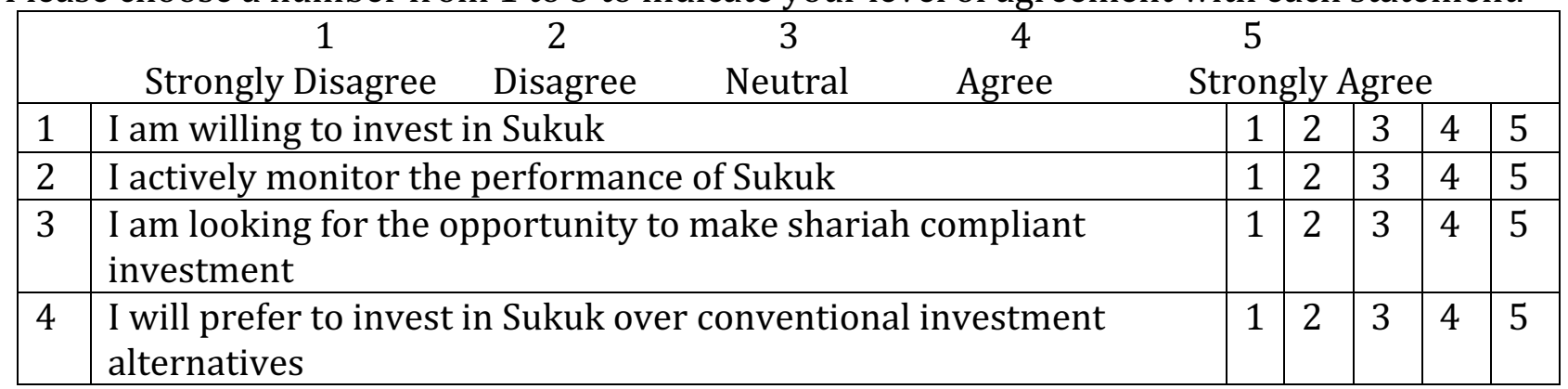

